\title{
Sodan kokemukset synnyttivät kotivaran
}

Jokapäiväisen ravinnon turvaaminen on aina ollut yhteiskuntien, perheiden ja yksilöiden keskeinen tavoite. Ravinnonsaanti voi heiketä luonnononnettomuuden, sodan, kuljetushäiriöiden tai esimerkiksi satomenetysten takia. Sitä voi vaikeuttaa yksittäinen tekijä tai useiden tekijöiden yhteisvaikutus. Pula ruoasta voi syntyä äkillisesti tai olla ennakoitavissa, ja se voi olla maailmanlaajuinen, alueellinen tai koskettaa yksittäisiä kotitalouksia.

Suomen elintarvikehuoltoa ovat merkittävästi vaikeuttaneet ensimmäinen ja toinen maailmansota ja niihin liittynyt elintarvikepula. Vaikka päävastuu maan elintarvikehuollon turvaamisesta on valtiovallalla, sotien yhteydessä tuli selvästi esiin kansalaisjärjestöjen merkitys väestön neuvonnassa ja käytännön ruokahuollon järjestämisessä. Olennaista näiden kriisien yhteydessä oli väestön omaehtoinen toiminta ja väestöä kannustettiin auttamaan itse itseään, kun yhteiskunnan mahdollisuudet olivat vähissä.

Suomalainen yhteiskunta ja sen elintarvikehuoltoa vaarantavat tekijät ovat 2020-luvulla monelta osin toiset kuin sotien aikaan. Myös kriiseihin varautuminen on muuttunut ja nälän ja puutteen torjunnasta on siirrytty aktiiviseen ennakolta varautumiseen ja jatkuvuudenhallintaan (1-3). Vaikka nykypäivän Suomi onkin varautunut elintarvikehuollon häiriöihin paremmin kuin koskaan aiemmin, verkottunut talous ja esimerkiksi riippuvuus ulkomaisista tuotantopanoksista lisäävät häiriöalttiutta (4-6). Kaupungistumisen myötä myös kotitalouksien riippuvuus palvelujen toimivuudesta on kasvanut. Tarvetta kotitalouksien häiriötilanteisiin varautumiselle ei välttämättä myöskään tunnisteta, koska kaupat ovat avoinna ympäri vuorokauden. $(5,7$.)

Tässä puheenvuorossa tarkastelen kotitalouksien aineelliseen varautumiseen, kotivaraan, liittyvää neuvontaa, sen tavoitteita ja vaiheita viimeisten viidenkymmenen vuoden aikana.

\section{NEUVONTAJÄRJESTÖJEN TÄRKEÄ ROOLI}

Ensimmäinen maailmansota romahdutti monen Euroopan maan elintarvikehuollon. Sodan vaikutukset ulottuivat Suomeen, vaikka varsinaiset sotatoimet eivät tänne yltäneetkään. Elintarvikkeiden hinnat nousivat ja vientiä rajoitettiin. Lopulta kulutusta oli säännösteltävä. Säännöstelyssä, kulutuksen tasaamisessa eri väestöryhmien ja alueiden kesken, ei täysin onnistuttu. Syynä olivat osin maan sisäiset kuljetusvaikeudet, mutta myös se, että omavaraiset kunnat pyrkivät ensisijaisesti varmistamaan oman toimeentulonsa. (8.)

Heikon elintarviketilanteen ei kuitenkaan katsottu johtuneen yksinomaan elintarvikkeiden niukkuudesta. Tuohon aikaan vallinneen yleisen käsityksen mukaan (9-10) ns. tavallinen kansa oli saamaton ja elintarvikepulan eräänä syynä pidettiin väestön tietämättömyyttä ja avuttomuutta. Nähtiin myös, että viljelytoiminta ja luonnontuotteiden hyödyntäminen oli ollut vähäistä. Väestöä moitittiin tuhlailevaksi, sen makutottumuksia kehittymättömiksi ja ruoanvalmistustaitoja heikoiksi. (11.) Tätä kuvastaa esimerkiksi maataloushallituksen ylijohtaja Uno Branderin toteamus nälänhädän torjuntaa käsittelevässä neuvottelukokouksessa elokuussa 1917: - - jos Suomen kansan makuasteikko olisi laajempi ja kehittyneempi, niin meidän ei tarvitsisi siinä määrin pelätä nälänhädän uhkaa, kuin meidän nyt on pakko tehdä (12).

Ruokapula tuntui etenkin kaupungeissa ja heikosti omavaraisilla syrjäseuduilla. Elintarviketilanteen heiketessä väestön ohjaukseen reagoivat ensimmäisinä yksittäiset kunnat ja neuvontajärjestöt. Esimerkiksi Helsingin kaupungin kalliinajan kotitalouskomitea järjesti kasvisruokakursseja ja havaintoesityksiä. Sen laatimissa ohjeissa otettiin ruoan ravitsevuuden lisäksi huomioon kohderyhmän varallisuus. Martta-yhdistyksen (nyk. Marttaliitto) toiminnassa korostuivat ruoanvalmistuskurssit. Päävastuu neuvonnan järjestämisestä oli kuitenkin senaatin 1917 nimittämällä valtion kotitaloustoimikunnalla. Yhteistyössä järjes- 
töjen kanssa se vastasi neuvonnan organisoinnista vaikeimpina pulavuosina. Neuvonnalla pyrittiin kohentamaan väestön ruoanvalmistustaitoja, lisäämään säästäväisyyttä ja hälventämään esimerkiksi luonnon raaka-aineisiin kohdistuneita ennakkoluuloja. (11.)

Toisen maailmansodan aikana elintarvikkeiden säännöstely oli Suomessa tiukka ja lähes kaikkien keskeisten elintarvikkeiden kulutusta rajoitettiin. Väestöä opastettiin sopeutumaan säännöstelymääräyksiin, omatoimisen tuotannon edistämiseen, luonnonkasvien hyödyntämiseen, ruoanvalmistuksen suunnitteluun ja elintarvikkeiden asianmukaiseen käsittelyyn. Palstaviljely lisääntyi, vaikka sen yleistymisen esteeksi havaittiin yhtäältä sodan aiheuttama rasitus ja toisaalta väestön osaamattomuus. Kuntien kotitalouslautakunnat osallistuivat myös pulantorjuntatyöhön, ja esimerkiksi Helsingissä aloitettiin uusina toimintamuotoina puhelinneuvonta ja neuvontatilaisuudet toreilla ja kauppahalleissa. (11.)

Viranomaisorganisaation ohella valistus- ja neuvontatyötä tekivät lukuisat järjestöt. Maatalousnaiset (nyk. Maa- ja kotitalousnaiset) suorittivat kotikäyntejä ja järjestivät kilpailuja. Marttaliiton ohjaus painottui havaintoesityksiin, koska säännöstely esti pitkäkestoisten ruoanvalmistuskurssien järjestämisen. Myös järjestöjen jäsenlehdissä ja keittokirjoissa annettiin opastusta. Eri poliittisia suuntauksia edustaneiden naisjärjestöjen perustama Pula-ajan Kotitalouskeskus tuotti neuvonta-aineistoa ja järjesti ruoanvalmistuskursseja. Neuvonta- ja tutkimustyön tiivistämiseksi perustettiin Kotitalouskeskus (myöh. Kotitalous- ja kuluttaja-asiain tutkimuskeskus), joka julkaisi opaskirjallisuutta, teki radio-ohjelmia ja piti pulantorjuntapäiviä. (11.)

\section{KOTIVARA 50 VUOTTA}

Sota- ja säännöstelyajan loputtua alettiin kiinnittää huomiota kansalaisten mahdollisuuksiin varautua aineellisesti elintarvikehuollon häiriöihin. Vuonna 1966 kauppa- ja teollisuusministeriö laati ohjeen Kotivara. Mitä se on? Objeita elintarvikkeiden kotivarastoinnista mahdollisten jakeluhäiriöiden varalle (13). Ohjeessa todettiin, että vaikka Suomi on nyt kohtalaisen omavarainen, se on monien hyödykkeiden osalta tuonnista riippuvainen. Vastuu väestön toimeentulosta todettiin olevan valtiovallalla, mutta kansalaisten omaa varautumista pidettiin tärkeänä. On mahdollista, että ohjeen laadintaan vaikutti silloinen kylmän sodan ilmapiiri ja kolmannen maailmansodan uhka (11).

Ohjeen mukainen "kotivarastointi" tarkoitti sitä, että kotitalouksiin hankitaan normaalia enemmän tärkeimpiä säilyviä elintarvikkeita, kuten viljavalmisteita, liha- ja kalasäilykkeitä, makaronia ja muita kuivavalmisteita. Tuontielintarvikkeista - sokerista, kahvista, teestä, suolasta ja saippuasta - annettiin määrällinen suositus kahden viikon kulutukseen. Ohjeessa otettiin kantaa myös kotivarasta aiheutuviin kuluihin. Kovin suurta menoerää kotivaran ei katsottu aiheuttavan, etenkin kun hankinnat on mahdollista tehdä vähitellen ja normaalihinnoin.

Kauppa- ja teollisuusministeriön esitettä ei sen saaman vastustuksen vuoksi jaettu koskaan kansalaisille. Ratkaisuun on esitetty vaikuttaneen poliittiset syyt (14) ja mahdollisesti pelko siitä, että esite aiheuttaa väestössä paniikkia (15). Kotivara-termiä on kuitenkin siitä lähtien käytetty tarkoittamaan kotitalouksien aineellista varautumista.

Kotitalouksien varautumista koskevan suunnittelutyön otti sittemmin tehtäväkseen Suomen Väestönsuojelujärjestö, joka julkaisi kuluttajille suunnatun kotivaraesitteen 1971. Järjestön toiminnassa olivat tuolloin ajankohtaisina radioaktiivisen laskeuman uhka ja säteilysuojaan liittyvät kysymykset. Siinä yhteydessä tuli esille myös kotitalouksien tarve varata elintarvikkeita väestönsuojaan suojautumista varten. Järjestön valtakunnallisille väestönsuojelupäiville tuottaman esitteen Miksi kotivara (16) lähtökohtana oli varautua tilanteeseen, jossa ulkopuolinen kriisi vaikeuttaa elintarvikkeiden ja muiden välttämättömyyshyödykkeiden tuontia. Siksi olisi huolehdittava, että "kotivara oli täydellinen" tuontituotteiden, kuten säilykehedelmien, sokerin, suolan, kahvin ja mausteiden osalta. Yksityiskohtaisesti laadittu ohje oli suunniteltu kahden viikon kulutukseen. Siinä oli myös ohje alle puolitoistavuotiaan lapsen ruoasta. Lisäksi esitteessä viitattiin väestönsuojaan suojautumisen edellyttämään varautumistarpeeseen (kotivaran ns. hälytyspakkaus) sekä evakuointitilanteeseen (kotivaran ns. evakuointipakkaus), mutta tuotiin esiin kotivaran merkitys myös yllätysvieraiden varalta.

Samoihin aikoihin myös valtiovalta palasi kotivarakysymykseen. Vuonna 1972 kouluille laa- 
dittiin sisäasiainministeriön väestönsuojeluneuvottelukunnan toimesta opetusohjelma Suojele itseäsi ja muita, jossa kotivara oli eräänä osaalueena. (17.)

Kuluneiden viidenkymmenen vuoden aikana kotivaran suunnittelusta on kantanut päävastuun Suomen Väestönsuojelujärjestö, sittemmin Suomen Pelastusalan Keskusjärjestö (SPEK). Ohjetta on sekä asiasisällön että ulkoasun osalta uudistettu useasti. Aiheesta on myös muuta opetus- ja neuvonta-aineistoa. (18.) Vuodesta 1996 lähtien kotitalouksien varautuminen ja kotivara on sisältynyt myös SPEK:n peruskoululaisille järjestämään turvallisuusopetukseen (NouHätä! -kampanja). Pelastus- ja väestönsuojelualan ohella kotitalouksien varautumiseen liittyvää neuvontaa ovat 1970-luvulta lähtien antaneet useat kotitalousalan ja maanpuolustuksen järjestöt paikallisyhdistyksineen. Neuvontatyössä ovat siis olleet mukana osittain ne samat tahot, jotka sotien aikana aktiivisesti opastivat kotitalouksia ruokahuoltoon liittyvissä kysymyksissä.

\section{KOTIVARAN VAIHEITA}

Kotitalouksien varautumisessa on ollut lähtökohtana, että pystyäkseen toimimaan normaalista poikkeavissa oloissa kotitalouksissa tulisi olla hyvin säilyviä ja helposti käytettäviä elintarvikkeita sisältävä varmuusvara. Kotivara tuli myös osata mieltää osaksi normaalia toimintaa, eikä esimerkiksi laatikolliseksi varastossa olevaa ruokaa. (17.) Ensi vaiheessa kotivaralla tarkoitettiin lähes yksinomaan elintarvikkeita. Myöhemmin siihen on sisällytetty muita välttämättömyystarvikkeita, kuten vesi ja henkilökohtaiset lääkkeet. Joditabletit mainittiin ensi kerran vuoden 1992 esitteessä. (18.)

Aluksi kotivaran aikajaksoksi määritettiin kaksi viikkoa. Sittemmin aikajaksoa on lyhennetty eri vaiheissa ja se on vaihdellut muutamasta päivästä viikkoon. (19-21.)

Ravitsemuksellisia ja terveydellisiä näkökohtia on eri vuosina painotettu vaihtelevasti ja joskus melko yksityiskohtaisestikin. Vuoden 1966 kauppa- ja teollisuusministeriön ohjeessa todetaan, että varastoa hankittaessa elintarvikkeiden "terveydelliset ja ravinto-opilliset vaatimukset on huomioitava". 1970- ja 1980-luvuilla ravitsemukselliset näkökohdat korostuivat erityisesti; kotivara kehotettiin koostamaan mahdollisimman täysipainoiseksi ja siten, että siitä saadaan energian lisäksi proteiinia, kuitua, vitamiineja ja kivennäisaineita. Myös monivitamiinivalmisteiden sisällyttämistä kotivaraan suositeltiin. Esitteessä ehdotetut ruoka-aineiden annosmäärät oli laskettu 2400 kcal:n, ”melko kevyttä työtä tekevän aikuisen päivittäiseen kulutukseen”. (22.)

Vuodesta 2017 SPEK on koordinoinut kotitalouksien omaehtoisen varautumisen konseptia, jossa kotivara on eräänä osa-alueena. Varautumisen ajanjaksoksi on siinä määritelty (vähintään) kolme vuorokautta eli 72 tuntia. (23.) Aikarajaus pohjautuu kansainvälisiin malleihin. 72 tuntia on sekä avustusjärjestöjen että viranomaisten yleisesti tunnistama aikakehys, jossa omatoiminen varautuminen helpottaa suuresti auttamispainetta; ${ }^{1}$ parhainkaan julkinen palvelu ei kriisitilanteessa kykene välittömästi vastaamaan kaikkiin tarpeisiin. 72 tuntia -konsepti on suunnattu etenkin kaupunkilaisiin naisiin ja nuoriin, sillä heillä tiedetään olevan vähiten kokemusta kriiseihin varautumisesta. (24.) Myös niissä kotitalouksissa, joissa arjen hallinta koetaan pulmalliseksi, varautuminen pahan päivän varalle saattaa jäädä huomiotta (25).

72 tuntia -suosituksessa kotivaran lähtökohtana on riittävä ruoan ja juoman turvaaminen. Elintarvikkeiden valinnassa korostetaan omien ruokatottumusten huomioimisen lisäksi hyvin säilyviä ja sellaisenaan syötäviä ruoka-aineita (26-27). Se, että käytettävissä on tuttuja elintarvikkeita, lisää turvallisuuden tunnetta.

\section{KOTIVARA TUTKIMUKSEN KOHTEENA}

Kotitalouksien elintarvikevarastointia koskeva suunnittelu ei ensi vaiheessa perustunut mihinkään erityiseen tutkimustietoon. Ensimmäisen kotivaraan liittyvän tutkimuksen teki Työtehoseuran kotitalousosasto 1970-luvulla. Aiheena oli opaslehtisen mukaisen kotivaran käyttö (14). Joitakin vuosia myöhemmin Työtehoseurassa selvitettiin neuvontaa tehneiden mielipiteitä kotivara-aineistosta ja kokemuksia neuvonnan tarpeesta (28).

Vuosikymmenten aikana on valmistunut yksittäisiä kotivaraan liittyviä opinnäytetöitä. Varhaisimmassa kartoitettiin helsinkiläistalouksien elintarvikevarastojen määrää ja koostumusta. Sittemmin kohteena ovat olleet muun muassa kotivara-asian opettaminen peruskoulussa, suoma-

\footnotetext{
1 "72 tuntia" on käytössä mm. San Francisco Cityssä, Japanissa, Kanadassa ja Ruotsissa.
} 
laisten suhtautuminen poikkeusoloihin varautumiseen ja siitä tiedottamiseen sekä opettajaopiskelijoiden suhtautuminen kotivaraan. (18) Vuonna 2020 valmistuneessa poikkeusolojen kulutustottumuksia käsittelevässä pro gradu -tutkielmassa (29) tarkastellaan myös kotitalouksien varautumista.

Harvinaislaatuinen tutkimusmahdollisuus tarjoutui vuonna 2000, kun Helsingissä toteutettiin kolme vuorokautta kestänyt väestönsuojakokeilu. Monen muun seikan ohella sen yhteydessä selvitettiin, millaisia elintarvikkeita suojakokeiluun osallistuneet varasivat mukaansa ja millaiseksi ruokailu väestönsuojassa muotoutui. Kyselyn perusteella elintarvikevalinnat vaihtelivat sekä määrältään että laadultaan ja kokeiluun näytti osallistuneen sekä "herkuttelijoita" että "askeetteja". Kokeilu osoitti myös elintarvikehygienian tärkeyden suojaolosuhteissa sekä ruoan ja ruokailun merkityksen viihtyvyyden kannalta. (30.) Radioaktiivisen laskeuman vaikutusta arvioitiin niin ikään 2000-luvun alussa kotitalouksien ja ruokapalvelusta vastaavien näkökulmasta. Siinä yhteydessä tuli esiin varautumisen ja kriisiaikaisen toiminnan edellyttämä tiedotustarve. (31-32.)

Kotivara ei ole ollut vain suomalainen ilmiö ja toimintatapa. Vuoden 1966 esitettä suunniteltaessa esimerkkeinä olivat Ruotsi ja Sveitsi. (Kauppa- ja teollisuusministeriö 1966). Vastaavia ohjeita on nykyäänkin esimerkiksi Ruotsissa (Civilförsvarsförbundet: Hemberedsskap), Saksassa (Bundesministerium für Ernährung und Landwirtschaft: Notvorrat), Sveitsissä (Schweizerische Eidgenossenschaft: Nortvorrat) ja Virossa (Päästeamet: Ole valmis!). Ohjeet perustuvat kunkin maan ruoankäyttö- ja ruokailutottumuksiin ja vaihtelevat esimerkiksi varautumista koskevan aikajakson suhteen.

\section{KOTIVARAN OMAKSUMINEN}

Kotitalouksien varautuminen on Suomessa aina ollut vapaaehtoista. Neuvonnassa sitä on perusteltu hätävarana yllätysvieraiden, sairastumisen, liikennehäiriöiden, sähkökatkosten ja varsinaisten poikkeusolojen näkökulmasta (esim. 19, 21).

Työtehoseuran aikuisväestön kotivaraneuvontaan liittyvän tutkimuksen yhteydessä 1987 ilmeni, että väestön suhtautuminen kotivaraan vaihteli äärimmäisyydestä toiseen. Joidenkin mielestä varautuminen "pahojen päivien varalle" luo turvallisuutta, toisten mielestä varautumisesta puhuminenkin on kriisitilanteiden hyväksymistä luonnolliseksi asiaksi. (28.)

Aihepiiriin suhtautumista kuvastavat osaltaan kotitalouksien varautumiseen liittyvät eduskuntakyselyt. Keväällä 1980 tiedusteltiin hallituksen toimia kotitalouksien kriisitilanteisiin varautumisen edistämiseksi (33). Ministerin vastauksessa todettiin valtiovallan haluvan toimillaan lisätä kiinnostusta yksityisten pienvarastojen hankkimiseen ja ylläpitämiseen. Pari vuotta myöhemmin tehdyssä eduskuntakyselyssä suhtautuminen kotivaran tarpeellisuuteen oli päinvastainen (34). Siinä nimittäin tiedusteltiin, mitä hallitus aikoo tehdä, jotta ihmisiä ei turhaan peloteltaisi keräämään itselleen kriisiajan varastoja. Kotitalouksien varautuminen oli niin ikään aiheena lokakuussa 1986 tehdyssä eduskuntakyselyssä (35).

Väestön suhtautumista kotivaraan ja sen omaksumista on kartoitettu 1960-luvulta lähtien Henkisen maanpuolustuksen suunnittelukunnan, Puolustustaloudellisen suunnittelukunnan, sisäministeriön ja Suomen Pelastusalan Keskusjärjestön toimesta. Eri vuosien kyselyt poikkeavat kuitenkin siinä määrin tavoitteiltaan, toteutuksiltaan ja kysymyksen asetteluiltaan toisistaan, ettei niiden perusteella voi arvioida varautumisen kehittymistä täsmällisesti. (18.) Vaikuttaa kuitenkin siltä, että vuosien myötä kotivara on kotitalouksissa yleistynyt. Vuoden 2015 kyselyssä kolmannes vastaajista arvioi pärjäävänsä kotona olevilla ruoka-, lääke- ja muilla tarvikkeilla yli viikon. (36.) Maaseudulla asuvat ovat kaupunkilaisia paremmin varautuneet pitkittyneisiin häiriötilanteisiin ja vastaava tilanne on omakotitalossa asuvilla kerros- ja rivitaloissa asuviin verrattuna (36-38). Äskettäin julkaistu raportti harvaan asuttujen alueiden turvallisuudesta osoittaa myös, että varautuminen häiriötilanteisiin on sitä parempi, mitä kauempana kuntakeskuksista asutaan. Kotivaran ohella tietotaito, varalämmitysjärjestelmät ja naapuriapu auttoivat esimerkiksi Kainuun tykkylumitilanteessa talvella 20172018. (39.) Myönteisintä kotivaraan suhtautuminen on vanhimmissa ikäryhmissä. Heikossa taloudellisessa asemassa olevat kotitaloudet ovat puolestaan huolestuneempia häiriötilanteissa pärjäämisestään ja häiriötilanteiden seurauksista taloudellisesti vahvoihin kotitalouksiin verrattuna. (38.) 
Kotitalouksien toiminta ja järjestöjen rooli varautumiseen liittyvässä neuvonnassa alettiin nähdä entistä tärkeämpänä koko elintarvikehuoltoketjun kannalta 2010-luvun alussa. Tuolloin Huoltovarmuusorganisaation elintarvikehuoltosektorin yhteyteen perustettiin kotitalouksien omatoimisen varautumisen järjestötoimikunta (Kova-toimikunta $)^{2}$. Sen tavoitteena on "järjestöyhteistyön kautta turvata ja kehittää laajasti kotitalouksien toimintakykyä häiriötilanteissa vahvistamalla valmiuksia omatoimisuuteen ja omavaraisuuteen”. Keskeisiä kysymyksiä elintarvikkeiden ohella ovat puhdas vesi, sähkö ja lämpö, välttämättömyystarvikkeet (esim. lääkkeet) sekä tiedon saanti häiriötilanteessa. (40.) SPEK:n koordinoimana Kova-toimikunta edistää jäsenjärjestöjensä kautta 72 tuntia -varautumissuositusta ja sen tunnettuutta useilla tavoin.

\section{VARAUTUMINEN KANNATTAA}

Elintarvikehuolto, kansalaisten ravinnonsaanti, on valtioneuvosten päätöksellä määritelty kaikissa oloissa turvattavaksi yhteiskunnan elintärkeäksi toiminnoksi ja yhdeksi huoltovarmuuden painopistealaksi (2). Nykypäivänä lähtökohta ei ole viime sotien kaltainen vahva valtio-ohjaus ja siihen perustunut elintarvikkeiden säännöstely. Sen sijaan pyrkimyksenä on yhteiskunnan ja elinkeinoelämän ennalta varautuminen ja markkinoiden toimivuuden ylläpitäminen kaikissa tilanteissa mahdollisimman lähellä normaalia. Viranomaisten tehtävänä on osaltaan varmistaa siihen vaadittavat toimintaedellytykset. (41.) Elintarvikehuoltoketjun toiminnalle kotitalouksien (aineellinen) varautuminen nähdään tällä hetkellä tärkeänä ja osana yhteiskunnan iskunkestävyyttä rakentavaa resilienssiä (40, 42-43).

Kokemuksia kuluttajien käyttäytymisestä elintarvikehuoltoa häiritsevissä tilanteissa on lähivuosilta vähän, ja ne liittyvät joihinkin lyhytaikaisiin tapahtumiin, kuten lakkoihin ja tuotantohäiriöihin. Niiden yhteydessä ilmennyt hamstraus on aiheuttanut niukkuutta ja jakelun epätasaisuutta, ts. pula on syntynyt ihmisten oman toiminnan takia. (esim. 11.)

2 Vuonna 2021 Kova-toimikuntaa kuuluu yhteensä 20 organisaatiota ja järjestöä, jotka edistävät yhteiskunnan huoltovarmuutta ja varautumista, luonnontuotteiden, riistan ja kalan talteenottoa ja käyttöä, kotiviljelyä sekä kotitaloutta ja ruokakulttuuria.
Ensimmäisiä ja osin alustavia arvioita covid19-pandemian vaikutuksesta koko ruokajärjestelmän haavoittuvuuteen (44), kuluttajien ostokäyttäytymiseen (esim. 45-46) ja ruokailun järjestämiseen kotitalouksissa (47) on julkaistu. Niiden perusteella tiedetään esimerkiksi, että rajoitusten vuoksi työikäisen väestön $(\mathrm{n}=1000)$ fyysinen kaupassakäynti väheni huomattavasti (46). Joustavuuden ja yhteistyön ansiosta päivittäistavarakaupan on arvioitu selvinneen poikkeuksellisesta tilanteesta hyvin. Alkuvaiheessa ilmennyt hamstraus - kuluttajien varautuminen karanteeniin tai esimerkiksi jonkin tuotteen mahdollisesti heikompaan saatavuuteen? - näkyi lyhytaikaisena kysyntäpiikkinä ja joidenkin tuotteiden hetkellisesti tyhjentyneinä hyllyinä. Tapahtuma osoitti kuitenkin, että hamstrauksen ja siihen liittyvien tekijöiden entistä monipuolisempi tutkimus on tarpeen. (48.)

SPEK:n joka toinen vuosi toteuttama omatoimiseen varautumiseen liittyvä kysely on parhaillaan suunnitteilla (49). Se tullee aikanaan heijastelemaan kansalaisten varautumiseen liittyviä näkemyksiä ja kokemuksia myös pandemian osalta. Toistaiseksi tiedossa on, että covid-19pandemia on lisännyt sekä median (50) että kansalaisten (27) kiinnostusta kotivaraan. Sitä osoittaa sekä erilaisten yhteydenottojen runsaus että neuvontajärjestöjen aihetta käsittelevien sivustojen kävijämäärän huomattava kasvu kuluneen vuoden aikana.

\section{LÄHTEET}

1 Laki huoltovarmuuden turvaamisesta 18.12.1992/1390.

https://www.finlex.fi/fi/laki/ ajantasa/1992/19921390

2 Valtioneuvoston päätös huoltovarmuuden tavoitteista 5.12.2018/1048. https:/www.finlex.fi/fi/laki/alkup/2018/20181048

3 Valtioneuvoston asetus Huoltovarmuuskeskuksesta 25.6.2008/455.

https://www.finlex.fi/fi/laki/ ajantasa/2008/20080455

4 Knuuttila M \& Vatanen E. Elintarvikemarkkinoiden tuontiriippuvuus. Helsinki: Luonnonvara- ja biotalouden tutkimus 70/2015, Luonnonvarakeskus; 2015.

https://jukuri.luke.fi/bitstream/ handle/10024/530860/luke-luobio_70_2015.pdf? sequence $=6 \&$ is Allowed $=y$ 
5 Huoltovarmuuskeskus. Ruokapalvelut osana päivittäistavarahuoltoa. Varautumisopas kunnille. Helsinki: Huoltovarmuuskeskus; 2017. https://www.huoltovarmuuskeskus. fi/ iles/41cbbb6534c3c855a162f 16cc712b32d14fa4dbf/ruokapalvelut_opas.pdf

6 Husu-Kallio J. Kokonaisturvallisuutta yhdessä \#5; Ruokahuolto ja kausityövoima. Luettu 18.5.2021. https://turvallisuuskomitea.fi/ kokonaisturvallisuutta-yhdessa-5-ruokahuolto-jakausityovoima

7 Valtioneuvoston selonteko ruokapolitiikasta. Ruoka2030. Suomi-ruokaa meille ja maailmalle. Luettu 3.5.2021. https:// mmm.fi/documents/1410837/1923148/ Ruokapoliittinen+selonteko+Ruoka2030/ d576b315-41fe-4e9d-9d02-8462c5ae5895

8 Rantatupa H. Elintarvikehuolto ja -säännöstely Suomessa vuosina 1914-1921. Jyväskylä: Studia Historica Jyväskyläensia 17, Jyväskylän yliopisto; 1979. http://urn.fi/URN:ISBN:978-951-39-4350-9

9 Heinonen V. Talonpoikainen etiikka ja kulutuksen henki. Kotitalousneuvonnasta kuluttajapolitiikkaan 1900-luvun Suomessa. Helsinki: Bibliotheca historica 33, Suomen Historiallinen Seura; 1998. http://urn.fi/URN:NBN:fi:ELE-493470

10 Harjula M. Terveyden jäljillä. Suomalainen terveyspolitiikka 1900-luvulla. Tampere: Tampere University Press; 2007. http://urn.fi/URN:ISBN:978-951-44-7058-5

11 Rautavirta K. Petusta pitsaan. Ruokahuollon järjestelyt kriisiaikojen Suomessa. Helsinki: Helsingin yliopisto; 2010. http://urn.fi/URN:ISBN:978-952-10-6303-9

12 Valtion kotitaloustoimikunta. Valtion kotitaloustoimikunnan neuvottelukokous Helsingissä elokuun 3-4 p:nä 1917. Helsinki: Suomen Senaatin kirjapaino; 1918.

13 Kauppa- ja teollisuusministeriö. Kotivara. Mitä se on? Ohjeita elintarvikkeiden kotivarastoinnista mahdollisten jakeluhäiriöiden varalta. Helsinki: Esite, Kauppa- ja teollisuusministeriö; 1966.

14 Sillanpää M-L. Esitutkimus kotivarasta. Helsinki: Työtehoseura; 1980.

15 Mikä ihmeen kotivara. Suomen sotilas 1995;1:2.

16 Miksi kotivara. Väestönsuojelulehti 1972;2:8.

17 Ahlström A \& Rautavirta-Hiekka K. Kotivara tutkimus- ja kehitystyön kohteena. Bolus 2000;2:22-24.

18 Rautavirta K. Ruokahuolto kriisiaikoina. Säännöstelystä suunnitteluun. Kirjassa: Nyström S. (toim.) Vaara ohi? Suomalainen väestönsuojelu kylmän sodan raunioilla. Helsinki: Väestönsuojelusäätiö \& Suomen Pelastusalan Keskusjärjestö; 2012, 140-155.

19 Suomen Pelastusalan Keskusjärjestö \& Huoltovarmuuskeskus. Kotivara. Elämän erityistilanteisiin. Helsinki: Esite, SPEK \& Huoltovarmuuskeskus; 2004.

20 Suomen Pelastusalan Keskusjärjestö. Kotivara jos kauppaan ei pääse. Helsinki: Esite, SPEK; 2009.
21 Suomen Pelastusalan Keskusjärjestö. Kotivara. Helsinki: Esite, SPEK; 2012.

22 Suomen Väestönsuojelujärjestö. Kotivara. Helsinki: Esite, Suomen Väestönsuojelujärjestö; 1982.

2372 tuntia - Varautuminen kotona. Ohjeita häiriötilanteiden varalle. Luettu 15.5.2021. https://72tuntia.fi/wp-content/uploads/2019/10/ Varautuminen-kotona-esite.pdf

24 Kunnaskari M \& Peltonen K. "72 tuntia” innostaa urbaaniin varautumiseen. Kirjassa: Huoltovarmuuden skenaariot 2030.

Helsinki: Huoltovarmuuskeskus; 2018, 57. https://www.huoltovarmuuskeskus.fi/ files/94603a5f9df0efb3789385a4ee77a7 f81284518f/huoltovarmuuden-uusi-normaali.pdf

25 Härmälä K \& Hopsu-Neuvonen A. Marttojen varautumistoiminta. Kirjassa: Kunnaskari M. (toim.) Kotitalouksien omatoimisen varautumisen tukeminen järjestöissä. Helsinki: SPEK tutkii 7, Suomen Pelastusalan Keskusjärjestö; 2014. https://issuu.com/spek_ry/docs/spek_tutkii_7; ks. myös Sekki S \& Autio M. Arkilähtöinen kotitalousneuvonta ja -kasvatus nuorten siirtymävaiheiden tukena. Sosiaalipedagoginen aikakauskirja, vuosikirja 2020; 21:9-37. https://doi.org/10.30675/sa.90106

26 Kolmen päivän kotivara. Luettu 17.5.2021. https://72tuntia.fi/wp-content/uploads/2020/02/ Kotivara_esite.pdf

27 Tuovinen E. Kotivara on ajattelutapa. Ravitsemusasiantuntija 2021;1:11.

28 Sillanpää M-L. Kotivaran neuvonta aikuisväestölle 1980-luvulla. Helsinki: Työtehoseura; 1987.

29 Lähteinen J. Tapaustutkimus suomalaisten lapsiperheiden kulutustottumusten muutoksista poikkeusolosuhteiden aikana. Joensuu: ItäSuomen yliopisto, soveltavan kasvatustieteen ja opettajankoulutuksen osasto, kotitaloustiede; 2020. http://urn.fi/urn:nbn:fi:uef-20201539

30 Seikkula E, Rautavirta-Hiekka K \& Ahlström A. Väestönsuojan ruokahuolto. Kirjassa: Ylinen R. (toim.) Suoja 2000. Helsinki: Helsingin pelastusliitto; 2000, 51-56.

31 Enqvist H. Preparedness of households and catering establishments for incidents involving radioactive contamination. J Environ Radioactivity 2005;83:415-419. https:/www.sciencedirect.com/ science/article/abs/pii/S0265931X05001049

32 Rantavaara A. Elintarvikeketjun suojaustoimenpiteet laskeumatilanteen varalle. Helsinki: Säteilyturvakeskus; 2005. https://www.julkari. fi/bitstream/handle/10024/123144/stuk-a215. pdf? sequence $=1$

33 Vp, kirjallinen kysymys n:o 137. Ruokatavaroiden varmuusvarastoinnista kotitalouksissa. 24.4.1980.

34 Putkiranta M. Suomen Väestönsuojelujärjestö 1927-1990. Helsinki: Väestönsuojelusäätiö; 1995.

$35 \mathrm{Vp}$, kirjallinen kysymys n:o 373. Elintarvikkeiden varaamisesta kriisitilanteisiin. 16.10.1986.

36 Laurikainen, H. Arjen ja asumisen turvallisuus. Puhelinhaastattelututkimus kansalaisten 
omatoimisesta varautumisesta. Helsinki: SPEK tutkii 12, Suomen Pelastusalan Keskusjärjestö; 2015.

https://issuu.com/spek_ry/docs/spek_tutkii_12

37 Laurikainen, H. Kotitalouksien varautuminen Suomessa. Puhelinhaastattelututkimus normaaliolojen häiriötilanteisiin varautumisesta. Helsinki: SPEK tutkii 13, Suomen Pelastusalan Keskusjärjestö; 2016. http://www.spek.fi/ loader.aspx?id=03718850-a8d7-4ced-90fc48432a6683f3

38 Laurikainen, H. Varautuminen ja kansalaisten kriisinkestävyys. Helsinki: SPEK tutkii 19, Suomen Pelastusalan Keskusjärjestö; 2019. https://issuu.com/spek_ry/ docs/spek_tutkii_19_ issuu

39 Lepistö J, Joentakanen J, Laurikainen H, Kekki T \& Harvaturva-verkosto. Harvaan asuttujen alueiden turvallisuus 2020. Tilanneraportti turvallisuudesta harvaan asutuilla seuduilla. Helsinki: Sisäministeriö; 2020. http://urn.fi/URN:ISBN:978-952-324-622-5

40 Kunnaskari, M. Kotitalouksien omatoimisen varautumisen tukeminen järjestöissä. Helsinki: SPEK tutkii 7, Suomen Pelastusalan Keskusjärjestö; 2014. https://issuu.com/spek_ry/docs/spek_tutkii_7

41 Työ- ja elinkeinoministeriö. Päivittäistavarahuolto vakavissa häiriötilanteissa ja poikkeusoloissa. Luettu 18.5.2021. https://tem.fi/ paivittaistavarahuolto-vakavissa-hairiotilanteissaja-poikkeusoloissa

42 Yhteiskunnan turvallisuusstrategia. Valtioneuvoston periaatepäätös 2.11.2017. Luettu 20.5.2021. https://turvallisuuskomitea.fi/wpcontent/uploads/2018/02/YTS_2017_suomi.pdf

43 Hyvönen A-E, Juntunen T, Mikkola H, Käpylä J, Gustafsberg H, Nyman M, Rättilä T, Virta S, Liljeroos J. Kokonaisresilienssi ja turvallisuus: tasot, prosessit ja arviointi. Helsinki: Valtioneuvoston selvitys- ja tutkimustoiminnan julkaisusarja 17/2019, Valtioneuvoston kanslia; 2019. https://julkaisut.valtioneuvosto. fi/bitstream/handle/10024/161358/17-2019. Kokonaisresilienssi\%20ja\%20turvallisuus. pdf? sequence $=1 \&$ isAllowed $=y$

44 Paloviita A, Silvasti T, Kortetmäki T \& Puupponen A. Ruokajärjestelmän haavoittuvuus koronaviruspandemialle. Elintarvike ja Terveyslehti 2020;3:6-10. https://jyx.jyu.fi/bitstream/ handle/123456789/72622/ET4-2020ss6-10. pdf? sequence $=1 \&$ is Allowed $=y$

45 Anttinen M, Hakola-Uusitalo T, Heinonen M, Järvelä K, Maliranta M, Saastamoinen M \& Sipiläinen M. Koronakriisin vaikutus kotitalouksiin. Helsinki: Selvityksiä 1/2020, Kilpailu- ja kuluttajavirasto; 2020. https:// www.kkv.fi/globalassets/kkv-suomi/julkaisut/ selvitykset/2020/kkv-selvityksia-1-2020koronakriisin-vaikutus-kotitalouksiin.pdf

46 Wilska T-A, Nyrhinen, J, Tuominen J, Šilinskas G \& Rantala E. Kulutus koronan aikaan - ja sen jälkeen. Jyväskylä: Jyväskylän yliopiston kauppakorkeakoulu; 2020. https://jyx.jyu.fi/bitstream/ handle/123456789/69106/978-951-39-8180-8. pdf? sequence $=1$ \&isAllowed $=y$

47 Corona cooking survey. Preliminary results, Finland. Luettu 21.5.2021.

https:/coronacookingsurvey.com/wp-content/ uploads/2020/06/Finland-rapport.pdf

48 Kulonen Lauri, valmiuspäällikkö/Huoltovarmuusorganisaatio, kauppa- ja jakelupooli, 21.5.2021.

49 Kekki Tuula, tutkimuspäällikkö/SPEK, 24.5.2021.

50 Räsänen Sanna, viestinnän asiantuntija/SPEK, 25.5.2021.

\author{
Kaija RautavirTa \\ ETT, yliopistonlehtori \\ Helsingin yliopisto \\ Kasvatustieteellinen tiedekunta
}

